\title{
Konsep Al Quran dalam menangani Konflik
}

\author{
Oleh : Rahmatullah ${ }^{1}$
}

\begin{abstract}
$* * *$
Abstrak

Islam adalah sebuah ajaran universal, yang mengajarkan kepada para pemeluknya agar dapat hidup dengan rukun dan damai. Ajaran perdamaian ini pada dasarnya merupakan titik tolak dari realisasi diutusnya Rasulullah sebagai rahmat bagi seluruh alam. Rahmat bagi seluruh alam merupakan konsepsi universal yang keluar dari batas-batas agama (dalam dimensi eksoteriknya), budaya, ras, suku, warna kulit dan lain sebagainya. Sejatinya, ajaran universal tentang perdamaian yang disampaikan oleh Rasulullah ini, mengarahkan umat Islam secara khusus dan umat manusia pada umumnya ke arah perkembangan dan perwujudan secara total terhadap nilai-nilai dimensi humanisasi. Pada gilirannya, perwujudan nilai-nilai humanis ini, akan mengantar pada penciptaan peradaban universal yang berakar dari pemahaman mendalam mengenai dimensi moral, ahlak dan etika.
\end{abstract}

\section{Kata kunci : Al Quran,Penanganan Konflik \\ PENDAHULUAN}

\section{A. Latar Belakang Masalah}

Pada zaman Rasulullah dan zaman khulafa al-Rasyidin, praktek perwujudan peradaban yang berakar dari pemahaman dimensi moral telah diwujudkan dengan baik. Ekspansi umat Islam ke daerah-daerah selain Islam dilakukan dengan tidak merusak peradaban daerah yang dikuasai, bahkan, yang bermanfaat diadopsi, dipelajari dan dikembangkan sehingga dikemudian hari melahirkan tokoh-tokoh besar diberbagai bidang keilmuan. Penguasaan berbagai bidang keilmuan yang dilakukan

\footnotetext{
${ }^{1}$ Dosen Tetap IAI Muhammadiyah Sinjai
} 
umat Islam selanjutnya menciptakan peradaban unggul dan menjadikan Islam berjaya selama beberapa waktu lamanya.

Pada konteks sekarang, umat Islam kehilangan momentumnya dalam mensinergikan moralitas sebagai landasan peradaban, sehingga umat Islam kemudian kehilangan identitasnya. Implikasi yang muncul dari kehilangan identitas tersebut adalah andil umat Islam dalam merumuskan konsep peradaban dalam konteks global maupun nasional akan dipandang "sebelah mata" baik secara internal maupun eksternal.

Oleh karena itu, secara umum, dibutuhkan pengkajian mengenai konsep Islam terhadap peradaban yang berakar dari pemahaman moral, etika dan akhlak. Apabila ini diteruskan maka benturan antar-peradaban yang menjadi issue sentral masalah peradaban akan dapat dipahami. Konflik yang terjadi akibat dari benturan peradaban tersebut dapat pula dipahami dan dikendalikan dengan baik. Secara khusus, dibutuhkan pangkajian atas konsep konkret Islam yang berdasar kepada moral, etika dan akhlak mengenai konflik yang menjadi issue turunan dari benturan antar-peradaban.

\section{B. Rumusan Masalah}

Rumusan masalah yang akan diangkat dari latar belakang masalah yang dikemukakan di atas adalah:

1. Apa yang menjadi latar belakang munculnya konflik?

2. Bagaimana konsep Islam menangani konflik? 


\section{PEMBAHASAN}

\section{A. Latar Belakang Munculnya Konflik}

Konflik tidak terjadi secara mendadak tanpa sebab dan proses, akan tetapi melalui serangkaian proses dan tahapan tertentu. Konflik diidentifikasi terjadi dengan 3 proses yakni 1) peristiwa sehari-hari, 2) adanya tantangan dan 3) timbulnya pertentangan. ${ }^{2}$ Peristiwa sehari-hari dapat dipahami dengan melihat adanya individu yang tidak puas dan jengkel terhadap lingkungannya. Perasaan tidak puas terkadang berlalu dan muncul kembali saat individu merasakan adanya gangguan.

Pada tahap kedua, apabila terjadi masalah, individu saling mempertahankan pendapat dan menyalahkan pihak lain. Masing-masing anggota menganggap bahwa perbuatan yang dilakukan sesuai dengan standar dan aturan organisasi. Kepentingan individu lebih menonjol daripada kepentingan organisasi. Pada tahap ketiga pertentangan merupakan proses terjadinya konflik. Pada ketiga ini, masing-masing individu dan kelompok bertujuan untuk menang dan mengalahkan kelompok lain. Fraksi-fraksi kecil berkembang dan kohesifitas kelompok dianggap lebih penting daripada kesiapan organisasi. ${ }^{3}$

Menurut Hardjana, konflik memiliki lingkarannya tersendiri yang terdiri dari 1) kondisi yang mendahului, 2) kemungkinan konflik yang dilihat, 3) konflik yang dirasa, 4) perilaku yang nampak, 5) konflik yang ditekan atau dikelola dan 6) dampak konflik. ${ }^{4}$ Prakondisi pada tahap pertama merupakan kondisi yang bersifat abnormal bagi masing-masing individu. Pada tahap kedua, individu telah melihat adanya perilaku kelompok atau individu lain yang menjadi penyebab kondisi abnormal yang dihadapi. Konflik pada tahap ketiga telah muncul dan dirasakan oleh masing-masing kelompok/individu yang berbeda yang kemudian melahirkan perubahan sikap dan tingkah laku hingga muncul pada tahap empat. Pada tahap kelima, konflik telah menjadi sebuah potensi yang sewaktu-waktu dapat merugikan apabila dikelola

\footnotetext{
${ }^{2}$ Hendrik, Bagaimana Mengelola Konflik (Jakarta: Bumi Aksara, 1992), h. 10.

${ }^{3}$ Ibid.

${ }^{4}$ Hardjana, Konflik di Tempat Kerja (Yogyakarta: Kanisius, 1994), h. 14.
} 
dengan pengelolaan yang buruk dan akan menguntungkan apabila dikelola dengan pengelolaan yang baik. Pada tahap selanjutnya konflik telah menuai hasil yang hasilnya sangat tergantung pada jenis pengelolaan yang dilakukan.

Model identifikasi konflik yang dikemukakan di atas pada dasarnya adalah model identifikasi konflik yang masih sangat sederhana. Menurut Susan, ada beberapa sumber konflik klasik yang diidentifikasi dari perkembangan analisa masyarakat dan didasarkan pada kemampuan individu memahami konflik, yakni: 1) Dinamika masyarakat dan sosiologi kelompok, 2) Konflik kelompok dan perjuangan kelas, 3) Kesadaran kolektif dan gerakan sosial, 4) Sosiasi dan konflik alamiah. ${ }^{5}$

\section{Dinamika masyarakat dan sosiologi kelompok}

Menjelaskan penomena sosial tidak sesederhana menjelaskan koherensi sosiologis dari satu masyarakat dengan masyarakat yang lain, baik secara vertikal maupun secara horisontal. Penomena sosial dan dinamika masyarakat yang menyertainya dalam Islam digambarkan sebagai berikut:

Pada abad ke-14, pada masa awal keruntuhan khalifah Abbasiyah akibat invasi bangsa Mongol. Masa ini ditandai dengan kekuasaan yang silih berganti dan tatanan politik yang labil. Berbagai kelompok kepentingan berbasis pada tribal melakukan gerakan kudeta terhadap kekuasaan negara sehingga menciptakan masyarakat dinamis secara politik. Konteks dinamika masyarakat dan konflik ini yang kemudian dianalisis oleh Ibnu Khaldun. Analisis tersebut melahirkan teori konflik kelompok dan hukum sosial konflik masyarakat. ${ }^{6}$

Gambaran yang dikemukakan di atas menunjukkan adanya gejala signifikan dari perkembangan dinamika masyarakat dan kondisi sosial kelompok. Dinamika tersebut dapat dilihat dari pertentangan-pertentangan yang muncul yang diklasifikasi dari berbagai macam sudut pandang, diantaranya; 1) pertentangan daulah antara

${ }^{5}$ Novri Susan, Pengantar Sosiologi Konflik dan Isu-isu Konflik Kontemporer (Jakarta: Kencana, 2010), h. 31.

${ }^{6}$ Josep Kuschel Agama Sebagai Sumber Konflik, terjemahan Imam Baihaqi (Yogyakarta: Pustaka Pelajar, 2003), h. 23. 
Daulah Abbasiyah dan Dinasti Mongol, 2) pertentangan antara pemerintahan yang sah dengan kelompok-kelompok perimbangan yang bergabung dalam komunitas tribal, 3) terciptanya masyarakat dinamis.

Pertentangan daulah yang terjadi adalah pertentangan yang meruntuhkan doktrin-doktrin peradaban yang ditelorkan masing — masing daulah, rezim, orde dan lain sebagainya. Pertentangan kelompok melahirkan keruntuhan tata nilai, budaya dan berbagai produk hukum dari sebuah negara. Kedua pertentangan di atas, yakni pertentangan daulah dan pertentangan kelompok melahirkan dekadensi dan dekonstruksi sosial yang parah dan memaksa masyarakat menciptakan proses pemenuhan kebutuhan yang bersifat empiris. Kondisi ini pada perkembangan selanjutnya akan menciptakan transendensi sosial atas kesadaran komitmen yang berujung pada dinamika masyarakat dalam berbagai bentuknya.

\section{Konflik kelompok dan perjuangan kelas}

Sumber konflik selanjutnya adalah pertentangan kelas yang diwujudkan dari pergeseran sosial akibat penelaahan kritis atas kondisi objektif yang dihadapi. Pergeseran sosial tersebut karena adanya perbedaan stratifikasi sosial yang muncul di masyarakat dan persebaran ekonomi yang tidak merata. Menurut Marx:

Kelas borjuis memiliki modal besar seperti uang dan nilai untuk menciptakan alat dan sistem reproduksi yang dengan itu sesungguhnya mereka telah meraih lebih dari sekedar kebutuhan dasar manusia. Mereka mengambil apa yang disebut “ over value of production” yang keuntungan dari seluruh proses produksi diambil secara keseluruhan. Proses ini menciptakan akumulasi modal di tangan kaum kapitalis atau kelas borjuis. Pada saat bersamaan kelas proletar dimiskinkan oleh sistem kapitalis sejak mereka tidak memeroleh keuntungan yang adil yakni hak-hak terhadap komoditas yang mereka ciptakan. Kelas proletariat menjadi tidak mampu memenuhi kebutuhan dasar mereka seperti pangan, pendidikan dan kesehatan. Kondisi ini akan diubah ketika kelas proletariat mendapatkan kesadaran kritis terhadap 
kejahatan kelas borjuasi dalam sistem kapitalisme. Kesadaran ini menciptakan revolusi proletariat melawan borjuisme dan sistem kapitalisme. Revolusi tersebut menciptakan suatu masyarakat tanpa kelas dan negara yang dihasilkan adalah negara yang dijalankan oleh kelas proletar pula. ${ }^{7}$

Penjelasan di atas apabila di perhatikan secara seksama terlihat bahwa pertentangan antar kelas merupakan sketsa yang "direncanakan" dengan baik. Perencanaan atas sketsa konflik antar kelas merupakan sebuah perencanaan yang didasarkan pada kenyataan yang ada dalam masyarakat yang menunjukkan adanya stratifikasi yang lahir dari perbedaan kemampuan memenuhi kebutuhan dasarnya. Ketidak-mampuan memenuhi kebutuhan dasar tersebut harus dihentikan dengan menyadarkan kaum proletar mengenai kondisi mereka yang "dimiskinkan" oleh sistem kapital yang megakumulasi modal secara tidak normal. Selanjutnya, penyadaran terhadap kaum proletar tersebut menyebabkan terjadinya revolusi baik struktural maupun kultur ekonomi masyarakat.

\section{Kesadaran kolektif dan gerakan sosial}

Kesadaran kelompok telah menjadi tema diskusi yang populer dalam diskusi sosial kritis masyarakat dunia ketiga. Pembahasan yang paling alot adalah seputar rekonstruksi fisik atas kemampuan masyarakat melakukan agregasi yang bersifat kongjungtif. Perumusan pola penyadaran juga menuai kontroversi karena melibatkan kontroversi pemikiran sosial-ekonomi Marxian. Walaupun tidak bisa dihindari bahwa tujuan penyadaran kelompok tersebut merupakan realisasi dari doktrin dialektika materialisme historis menuju masyarakat yang mampu melakukan revolusi. Marx menyatakan: " ...of all instruments of production the greatest force of production is the revolutionary class itself...". 8

\footnotetext{
${ }^{7}$ Karl lowith, Max Weber dan Karl Marx (London: Routledge, 1993), h. 43.

${ }^{8}$ Ralf Dahrendorf, Class and Class Conflict in Industrial Society (California: Stanford University Press, 1959), h. 9
} 
Provokasi Marx di atas mengindikasikan adanya dua hal yakni 1) kekuatan produksi terbesar adalah kekuatan kaum revolusioner dan 2) kekuatan revolusioner sejati adalah kekuatan kaum buruh yang mengalami kesadaran kolektif mengenai posisinya kelasnya. Marx tidak mendefinisikan kelas secara panjamg lebar tetapi ia menunujukkan bahwa dalam masyarakat, pada waktu itu, terdiri dari kelas pemilik modal (borjuis) dan kelas pekerja miskin sebagai kelas proletar. ${ }^{9}$ Kedua kelas ini berada berada dalam struktur sosial yang hierarkis, dan berjuis melakukan ekploitasi terhadap proletar dalam sistem produksi kapitalis. Pendefinisian struktur kelas ini tidak lepas dari konteks pada waktu itu ketika perubahan struktur masyarakat begitu dominan dipengaruhi oleh distribusi modal dalam perubahan cara produksi.

Eksploitasi ini terus berjalan karena masih mengakarnya kesadaran semu, false consciousness, dalam diri proletar, yaitu rasa berserah diri, menerima keadaan, dan berharap balasan akhirat. Melalui perspektif ini, Marx menilai agama adalah candu yang mengantar manusia pada halusinasi kosong dan menipu. Agama sebagai lembaga sosial tidak lebih dari instrumen pragmatis kelas borjuis yang melanggengkan model produksi ekonomi kapitalis. ${ }^{10}$ Pandangan inilah yang pada perkembangan selanjutnya melahirkan gagasan untuk mengeluarkan agama dari polaritas pemeluknya dan memisahkan agama secara tajam dari kehidupan sosial dan berujung pada terwujudnya konflik ekstrem intern dan ekstern agam itu sendiri.

\section{Sosiasi dan alamiah}

Teori sosiasi dan konflik alamiah dapat dipahami dengan memahami penjelasan Simmel mengenai konflik, dengan mengemukakan konsep "geometry of social space”, berikut ini:

Simmel memberi perspektif hubungan konflik dan mediasi yang menarik. Simmel menggambar hubungan dyad (dyadic relationship) dan triad (triadic relationship). Dalam hubungan dyad yang terdiri dari dua peserta, sifat hubungan itu adalah konfrontatif. Pengertian

\footnotetext{
${ }^{9} \mathrm{http}: / /$ www.marxists.org/.

${ }^{10}$ Ibid.
} 
integratifnya, dua peserta saling bergantung satu sama lain karena kepergian satu partisipn akan menghancurkan hubungan tersebut. Perubahan populasi, dari dyad menjadi triad memberi perubahan kualitatif yang mendasar. Dalam hubungan triad, salah satu peserta mungkin akan ditinggalkan oleh koalisi dua peserta lainnya. Strategi lainnya yang mungkin adalah kemunculan satu peserta sebagai mediator yang menjaga kelompok terus berinteraksi positif dengan menciptakan kesepakatan. Sebaliknya, moderator biasanya menciptakan konflik terus menerus untuk keuntungannya sendiri. Selanjutnya, ketika konflik menjadi bagian dari interaksi sosial, maka konflik akan menciptakan batasan-batasan antar kelompok dengan memperkuat kesadaran internal yang membuat kelompok tersebut terbedakan dan terpisah dari kelompok lain. Hal ini berlaku secara resiprokal, anntagonistik atau permusuhan timbal balik. ${ }^{11}$

Penjelasan Simmel di atas, menunjukkan bahwa penyebab konflik alamiah adalah adanya proses sosiasi yang terjadi dalam internal kelompok masyarakat. Sosiasi tersebut bersifat kerjasama baik dalam bentuk kerjasama 2 individu atau kelompok dan kerja 3 individu atau kelompok. Adapun proses-proses penyebab konflik yang terjadi merupakan implikasi dari proses pemenuhan yang tidak berbanding dengan harapan terwujudnya pemenuhan yang telah direncanakan sebelumnya.

\section{B. Metode Penanganan Konflik dalam Islam}

Kebutuhan keamanan, ketentraman dan kedamaian adalah kebutuhan manusia yang sangat asasi, bahkan dalam fiqh kebutuhan tersebut termasuk dalam dharuriyat al-khamsah. Oleh karena itu, pengupayaan kepada nilai tersebut

${ }^{11}$ Novri Susan, Op. cit., h. 48, lihat juga dalam George Simmel, the Sosiologi of Conflict (USA:American Journal of Sociology, 1903), yang dimuat ulang oleh Wallace \& Wolf, Reading in Contemporary Sociologycal Theory From Modernity to Post-Modernity (New Jersey: Prentice Hall, 1995), h. 185 
merupakan suatu hal yang sangat terhormat. Dalam hal ini, Islam telah memberikan metode penanganan dari segala gangguan keamanan, ketentraman dan kedamaian yang disebut dengan istilah islah.

Secara bahasa ishlah berasal dari kata الصلح yang berarti baik dan bagus, kata tersebut sering dilawankan dengan kata فسد (rusak). Dalam pemakaiannya kedua kata tersebut dipakai dalam konteks verbal. ${ }^{12}$ Sementara kata اصلح biasanya dipakai untuk menghilangkan persengketaan di kalangan manusia. ${ }^{13}$ Tetapi jika dipakai oleh Allah kadang-kadang dilakukan dengan melalui proses penciptaan yang sempurna. Kadang-kadang dengan menghilangkan suatu kejelekan atau kerusakan setelah keberadaannya dan kadang-kadang dengan melalui penegakan hukum (aturan) terhadapnya. $^{14}$

Ibrahim Madkour dalam al-Mu'jam al-Wajiz mengatakan bahwa kata ishlah mengandung tiga makna; manfaat dan keserasian serta terhindar dari kerusakan. Jika kata tersebut berbentuk imbuhan maka berarti menghilangkan segala sifat permusuhan dan pertikaian antara kedua belah pihak. ${ }^{15}$ Sementara itu, Ibnu Mandzur dalam Lisanul 'Arabnya berpendapat bahwa kata ishlah biasanya mengindikasikan rehabilitasi setelah terjadi kerusakan, sehingga dimaknai dengan iqâmah". ${ }^{16}$

Lafadz al-ishlah juga memiliki beberapa sinonim, diantaranya adalah tajdid (pembaharuan), taghyir (perubahan) yang keduanya mengarah kepada kemajuan dan perbaikan kondisi. Maka dalam hal ini, ishlah bertalian erat dengan tugas para Rasul yang ditindaklanjuti hingga sekarang. Disamping itu, ishlah juga merupakan bentuk kesepakatan antara kedua belah pihak yang mengadakan perbaikan dengan jalan damai, baik dalam keluarga, sosial maupun dalam peperangan dan lain-lain. ${ }^{17}$ Dalam

\footnotetext{
${ }^{12}$ Lih. QS. At-Taubah: 102, QS. Al-A'raf: 85

${ }^{13}$ Abi Muhammad Mahmud al-Ainainy, al-Binayah fi Syarh al-Hidayah (Beirut:Dar al-Fikr, Juz IX, t.t), h. 3

${ }^{14}$ Ar-Raghib al-Asfahany, Mu'jam Mufradât Alfâdz al-Quran (Beirut: Dar al-Fikr, tt), h.292

${ }^{15}$ Ibrahim Madkour, Al-Mu'jâm al-Wajîz, (t.p., t.t.), h. 368

${ }^{16}$ Ibnu Mandzûr, Lisân al-A'Arab (Beirut: Dar al-Fikr, 1993), h. 518

${ }^{17}$ Hasbi ash-Shiddiqy, al-Islam II (Jakarta: Bulan Bintang, 1952), h. 448
} 
sosialisasi pergaulan, sikap emosi antara individu satu dengan yang lain bervariatif. Ada yang bertemperamen rendah (sabar), ada yang sedang dan ada yang tinggi, sehingga wajar jika terkadang terjadi perselisihan dalam bersosialisasi.

Oleh karena itu, mengantisipasi hal tersebut Islam menyediakan sebuah lembaga ishlah jika memang perselisihan tidak dapat dihindari. Dalam proses penyelesaian konflik, Islam mendorong dan memberikan penghargaan bagi mereka yang lebih dahulu mengedepankan sikap legowonya melalui ishlah.

Penguatan Islah sendiri dilakukan dengan menyertakan beberapa karakter agar hasil islah menjadi bermanfaat bagi semua orang. Adapun beberapa konsep penguat dari Islah terdiri dari empat hal yakni: 1) Diniatkan karena Allah swt., 2) dilakukan dengan sabar, 3) Istiqamah atau konsisten pada kesepakatan yang dicapai dan 4) saling menghormati.

Adapun yang menjadi tujuan Islah adalah sebagai berikut:

1. Upaya pro aktif terhadap gejala sosial atau individu semata-mata untuk menjaga agar tidak terjadi konflik yang lebih besar.

Dalam konteks ini, ishlah yang diupayakan adalah pencegahan terhadap sesuatu yang sangat berpotensi untuk berkembang, baik perkembangan tersebut menuju konflik jika tidak segera diatasi, maupun potensial berkembang untuk mencapai kedamaian dan kesejahteraan jika segera ditangani.

Pujian al-Quran terhadap orang yang menerima dan melaksanakan apa yang disampaikan para Rasul lalu mereka mengadakan perbaikan terhadap kesalahan yang mereka kerjakan hingga datangnya petunjuk. Upaya perbaikan tersebut merupakan potensi dasar yang akan berkembang dan memberikan jaminan keamanan serta terhindar dari rasa ketakutan dan kesedihan. Pendek kata, bahwa keimanan dan upaya perbaikan (ishlah) akan membebaskan diri manusia dari rasa takut dan sedih, karena rasa takut dan sedih inilah yang senantiasa menghalangi dinamika dan kreatifitas manusia.

2. Upaya yang merupakan prasyarat diterimanya taubat dan diberikan ampunan. 
Dalam konteks ini, ishlah yang merupakan prasyarat diterimanya taubat dan diampuni oleh Allah, jika dilihat dari isyarat ayat dapat dikelompokan menjadi dua; pertama, ishlah yang diupayakan hanya dengan merehabilitasi perilaku, baik tabi'at, tingkah laku, ucapan dan lain-lain. Kedua, ishlah yang diupayakan harus diikuti dengan pertanggungjawaban kerusakan yang telah dilakukan baik dengan mengembalikan, merehabilitasi maupun menanggung proses pemeliharaan sehingga hak-hak atau kewajiban antara sesama terselesaikan.

3. Upaya ishlah bukan dari sengketa dua kelompok yang berperkara, tetapi perbaikan dari perbuatan keji yang dilakukan oleh dua kelompok secara kooperatif.

Upaya ishlah yang dilakukan diatas adalah ishlah yang datang dari satu pihak, baik individu atau kelompok. Sementara dalam konteks ini, ishlah tersebut datang dari kedua belah pihak terhadap perbuatan keji yang mereka lakukan secara kooperatif.

\section{Contoh Penanganan Konflik}

Metode penanganan konflik secara konsepsional yang telah diuraikan sebelumnya adalah sebuah metode penanganan yang cukup ideal untuk diterapkan. Dalam konteks ke-Indonesiaan sendiri, belum ada penerapan metode penanganan konflik yang merangkum metode penanganan konflik dalam Islam secara komprehensif. Akan tetapi, perwujudan metode penanganan konflik yang sesuai dengan konsep Islam masih terjadi secara terpisah-pisah dan diupayakan untuk sesuai dengan konteks etno-sosio-historis dari masyarakat setempat.

Sebagai contoh, metode penanganan konflik di Ambon yang diwujudkan pada tujuh butir rumusan resolusi konflik Ambon yakni 1) urgensi pendidikan berbasis multikulturalisme, 2) menghidupkan kembali budaya positif untuk saling menghargai dan menyayangi sesama, 3) menciptakan kebijakan yang proporsional dengan mengakomodasi potensi yang ada dalam seluruh elemen masyarakat khususnya mereka yang selama ini terabaikan harus mendapat porsi yang wajar, 4) adanya upaya untuk mengintegrasikan conflict analysis dan penilaian keadaan yang 
kontekstual bagi elemen yang ada, 5) upaya untuk meredam konflik harus bermuara pada dua hal yakni penegakan hukum dan kejujuran hati dalam bersikap dan bertindak, 6) khusus bagi pengunsi untuk ditangani dengan lebih manusiawi, 7) rehabilitasi basis infrastruktur masyarakat dengan mendorong penyediaan dan pelayanan jasa publik.

Kasus konflik buruh yang berdasar kepada teori Marx seperti yang terjadi pada kasus demonstrasi buruh di seluruh Indonesia yang menjadi refleksi dari tarik menarik kepentingan antara kepentingan kaum buruh dan kepentingan majikan. Gejala konflik tersebut terjadi ketika harga BBM naik maka secara otomatis menaikkan harga seluruh barang pokok. Ketika harga barang pokok naik maka harga dibutuhkan sumber persediaan yang dapat menanggulangi kebutuhan tersebut. Dalam Islam konflik tersebut dapat diselesaikaan dengan melibatkan pemerintah sebagai regulator yang berusaha menyeimbangkan kondisi pasar. Apabila upah buruh belum cukup untuk mencapai kesejahteraan buruh maka pemerintah menetapkan standar minimal yang tidak mendistorsi harga pasar. ${ }^{18}$

Dari resolusi-resolusi atas permasalahan di atas, terlihat bahwa solusi konsepsional dalam Islam masih harus berbenturan dengan kondisi objektif di lapangan. Olehnya itu dibutuhkan kecermatan dan kejelian seorang resolutor untuk memahami kondisi konflik seobjektif mungkin dan menerapkan konsep-konsep Islam dalam penyelesaiannya.

\footnotetext{
${ }^{18}$ Penjelasan lengkap mengenai perpotongan kurva dan garis ekuivalen diantaranya dapat dilihat secara lengkap dalam Thoha Hamim, Resolusi Konflik Islam Indonesia (Yogyakarta: LKiS, 2007), h. 180
} 


\section{KESIMPULAN}

Kesimpulan dari makalah yang diuraikan di atas adalah sebagai berikut:

1. Latar belakang munculnya konflik adalah karena benturan kepentingan berbagai pihak, baik kepentingan pribadi, golongan maupun ideology dan politik.

2. Konsep penanganan konflik dalam Islam adalah memulai dengan berusaha menyentuh substansi konflik dan mencari titik temu di dalamnya, dalam proses penanganannya adalah dengan mempertimbangkan dimensi teologis, humanis dan naturalis sedangkan pada akhirnya adalah penerimaan atas dasar kesadaran dari masing-masing pihak atas keputusan yang diambil. Hal tersebut ditemukan konsep Islah. 


\section{Daftar Pustaka}

Abi Muhammad Mahmud al-Ainainy, al-Binayah fi Syarh al-Hidayah (Beirut:Dar al-Fikr, Juz IX, t.t)

Ar-Raghib al-Asfahany, Mu'jam Mufradât Alfâdz al-Quran (Beirut: Dar al-Fikr, tt)

Hamim, Thoha. Resolusi Konflik Islam Indonesia (Yogyakarta: LKiS, 2007)

Hardjana, Konflik di Tempat Kerja (Yogyakarta: Kanisius, 1994)

Hasbi ash-Shiddiqy, al-Islam II (Jakarta: Bulan Bintang, 1952)

Hendrik, Bagaimana Mengelola Konflik (Jakarta: Bumi Aksara, 1992

http://www.marxists.org/.

Ibnu Mandzûr, Lisân al-A'Arab (Beirut: Dar al-Fikr, 1993)

Ibrahim Madkour, Al-Mu'jâm al-Wajîz, (t.p., t.t.)

Josep Kuschel Agama Sebagai Sumber Konflik, terjemahan Imam Baihaqi (Yogyakarta: Pustaka Pelajar, 2003)

Karl lowith, Max Weber dan Karl Marx (London: Routledge, 1993)

Novri Susan, Pengantar Sosiologi Konflik dan Isu-isu Konflik Kontemporer (Jakarta: Kencana, 2010)

Ralf Dahrendorf, Class and Class Conflict in Industrial Society (California: Stanford University Press, 1959)

Susan, Novri, MA. Pengantar Sosiologi Konflik dan Isu-isu Konflik Kontemporer (Jakarta: Kencana, 2010)

Tgk. H. Ibrahim Bardan, Resolusi Konflik dalam Islam (Nangroeh Aceh Darussalam: the Aceh Institute, 2008)

Thoha Hamim, Resolusi Konflik Islam Indonesia (Yogyakarta: LKiS, 2007)

Wahyudi, Dr., Manajemen Konflik dalam Organisasi (t.t: al-Fabeta, 2008)

Wallace \& Wolf, Reading in Contemporary Sociologycal Theory From Modernity to Post-Modernity (New Jersey: Prentice Hall, 1995

Zada, Khamami, dkk, Prakarsa Perdamaian; Pengkajian dari Berbagai Konflik Sosial (Lakpesdam NU: Jakarta, 2008) 